\author{
М.Ф. Пічугін ${ }^{1}$, Я.М. Кожушко ${ }^{1}$, Д.А. Іщенко ${ }^{2}$, В.А. Кирилюк ${ }^{2}$, С.Д. Іщенко ${ }^{3}$ \\ ${ }^{1}$ Харківський національний університет Повітряних Сил ім. І. Кожедуба, Харків \\ ${ }^{2}$ Житомирський військовий інститут ім. С.П. Корольова, Житомир \\ ${ }^{3}$ Військова частина А0515, Київ
}

\title{
ВИЗНАЧЕННЯ ВАЖЛИВОСТІ ОБ'ЄКТІВ СПОСТЕРЕЖЕННЯ КОСМІЧНИМИ ЗАСОБАМИ В ІНТЕРЕСАХ ІНФОРМАЦІЙНОГО ЗАБЕЗПЕЧЕННЯ ГРУП КОСМІЧНОЇ ПІДТРИМКИ
}

\begin{abstract}
У статті показано необхідність удосконалення методичного апарату інформаційного забезпечення космічної підтримки всіх видів діяльності Збройних Сил в угрупованнях військ (сил), у тому числі на тактичному рівні. Запропонований методичний апарат оцінювання об 'єктів спостереження та космічних засобів спостереження - джерел інформації про них, який може використовуватися при організації такого спостереження в інтересах ефективного застосування військ (сил) за призначенням з врахуванням потреби рачіонального використання наявних можливостей космічної підтримки.
\end{abstract}

Ключові слова: важливість, дистанщійне зондування землі, знімання, інформація, космічна підтримка, спостереження.

\section{Вступ}

Аналіз досвіду антитерористичної операції та операції Об'єднаних сил (ООС) показує необхідність удосконалення спостереження за об'єктами військ (сил) противника та заданими районами (далі - об'єктами) [1], у тому числі на тактичному рівні, 3 використанням матеріалів космічного знімання (MK3).

Організація спостереження має здійснюватись в інтересах раціонального використання наявних сил і засобів, а також в інтересах ефективного застосування військ (сил) за призначенням [2-5] з урахуванням потреби раціонального використання наявних сил і засобів космічної підтримки та ресурсів, призначених на отримання МКЗ, що обумовлює важливість космічного спостереження для виконання завдання викриття об'єктів противника в інтересах ефективного використання засобів ураження [6-8] та подавлення [9-10].

Постановка проблеми. В умовах ресурсних обмежень для досягнення переваги над противником у силах та засобах ведення бойових дій, задача визначення важливості об'єктів та джерел інформації є обов'язковим елементом організації спостереження з використанням космічних засобів, вирішення якої передбачає наявність відповідного методичного апарату. Недосконалість такого апарату обмежує ефективність сучасних засобів впливу на противника за ступенем реалізації просторово-часових можливостей у разі змін важливості об'єктів у часі, що викликає необхідність вирішення такого завдання.
Аналіз останніх досягнень та публікацій показав, що за відсутності методичного апарату визначення важливості об'єктів спостереження (далі OC) та космічних засобів - джерел інформації про них (далі - КЗДІ), для його розроблення може бути визначена певна теоретична база, підгрунтям формування якої можуть прийняти результати багатьох наукових досліджень вітчизняних та закордонних авторів. Узагальнені підходи, які можна застосовувати до визначення важливості об'єктів і джерел спостереження надано у низці робіт. Основні принципи визначення категорій важливості (важливих, першочергових (найважливіших) об'єктів, тощо) противника за категоріями розглянуто у публікаціях [11-13]. У [14-17] узагальнені підходи до визначення важливості об'єктів та джерел адаптовано до особливостей технічного виду спостереження. У наведених роботах розглядаються питання вербального визначення важливості об'єктів і джерел без формалізованого у математичному вигляді порядку (методики) встановлення узагальненого критерію та ступеню їх важливості.

Підхід до оцінювання важливості об'єктів противника за показником збитку, який він наносить військам (силам) описано в [16]. Роботи [14-15; 17] присвячені методу аналізу ієрархій та порівняльному оцінюванню об'єктів. Матеріал, наявний у наведених джерелах, може використовуватися для розроблення методичного апарату визначення важливості ОС та КЗДІ.

У більшості робіт, присвячених оцінюванню об'єктів противника, розглянуто важливі, але лише 
окремі сторони цієї проблеми - визначення їх бойових потенціалів. Питанням врахування інформативності, надійності та комплексної доступності, що визначає можливість, корисність та доцільність замовлення МКЗ від КЗДІ - КА певних систем, що є найбільш корисними для спостереження визначених відповідно до пріоритетів за важливістю об'єктів, потрібних для зменшення ефективності їх застосування противником, не приділено достатньо уваги.

Проведений аналіз останніх досліджень і публікацій за тематикою дозволяє стверджувати про наявність певних науково-практичних результатів у цій сфері. Проте відомі існуючі науково-методичні матеріали мають фрагментарний характер та недостатній рівень формалізації, що затрудняє їх застосування безпосередньо в практичній діяльності військ (сил), зокрема груп космічної підтримки (ГКП). У відомих авторам роботах не визначено цілісного методичного апарату, що надавав би практичні рекомендації з визначення важливості ОС та КЗДІ про них.

Аналіз існуючих відомих положень та підходів щодо їх використання у якості елементів методичного апарату визначення пріоритетності та важливості об'єктів і джерел інформації, дозволяє стверджувати про можливість їх вдосконалення щодо формалізації та адаптації до особливостей завдань, об'єктів і джерел космічного спостереження.

Таким чином, мета статті полягає у отриманні методичного апарату визначення важливості ОС та КЗДІ про них та наведенні прикладів умовних розрахунків.

\section{Виклад основного матеріалу}

Важливою складовою планування спостереження наземних об'єктів з використанням КЗДІ про них (далі - спостереження), є розподіл ресурсів спостереження за завданнями, об'єктами, який відображається у відповідному документі з планування, наприклад - Плані спостереження (бойового (оперативного) забезпечення). Розподіл ресурсів спостереження передбачає здійснення визначення важливості ОС та КЗДІ, по яким вони розподіляються, функціонують, утворюючи систему спостереження.

Загальним знаменником функціонування органів космічної підтримки (КП) всіх рівнів є ефективність виконання завдань спостереження. Завданням підвищення ефективності спостереження $\epsilon$ об'єктивне оцінювання важливості ОС та КЗДІ. Одним 3 показників, що дозволяє оцінювати ефективність спостереження, є визначення важливості ОС. Встановлення категорії важливості об'єкту (особо важливі, важливі, першої, другої категорії тощо) впливає на вимоги до якості своєчасної інформації про нього (оперативність, точність, достовірність, повнота, тощо), що визначається тактикотехнічними показниками (показниками якості) КЗДІ. Врахування різноманіття можливих показників та критеріїв оцінювання КЗДІ та ОС різних видів, класів, підкласів, типів, потребує суб'єктивних вимірювань за підходом, що використовує можливості інформаційних технологій. Для здійснення суб'єктивних вимірювань застосовуються різні методи, найбільш поширеними 3 яких $є$ [14-15]: ранжування; парне порівняння; безпосереднє оцінювання; послідовне порівняння.

Визначення важливості ОС та КЗДІ про них базується на загальному порядку визначення важливості об'єктів з використанням методу аналізу ієрархій (MAI) [17], за яким здійснюється ієрархічна декомпозиція проблеми визначення важливості ОС та КЗДІ про них на все більш прості складові частини та подальше оброблення послідовності суджень (оцінювання) експерта (особи) відносно парних порівнянь.

Загальний порядок визначення важливості ОС 3 використанням MAI реалізовано відповідно до побудованої ієрархічної моделі оцінювання важливості об'єктів (рис. 1), що умовно відповідає структурі системи об'єктів зі складу угруповання військ (сил) противника, за яким повинно бути організовано спостереження, за результатами якого група космічної підтримки (далі - ГКП) здійснює інформаційне забезпечення військ (сил), якість якого забезпечує зменшення збитку своїх військ (сил) та збільшення збитку противника.

На верхньому рівні ієрархічної моделі спостереження угруповання військ (сил) противника є ціль (фокус ієрархії) зменшення збитку військ (сил) та збільшення збитку угруповання військ (сил) противника, що пояснюється потребою своєчасно виявити ознаки безпосередньої підготовки угруповання військ (сил) противника до нанесення збитку військам (силам) та нанести збиток до початку його дій (до нанесення збитку) по військам (силам).

Нанесення збитку військам (силам) противник здійснює цілеспрямованою діяльністю своїх ОС угруповання - структурних елементів (А, Б, В, Г), що входять до його складу. За складом сил і засобів, бойовими потенціалами та можливостями ОС відрізняються, що визначає різний вклад кожного з них у загальний нанесений збиток.

На рис. 1 позначені показники (критерії) оцінювання КЗДІ (доступність, інформативність, новизна, належність (МКЗ від КЗДІ безпосередньо до ОС), надійність), та ОС (j) (внесок ОС у збиток (що завдає противник), універсальність застосування ОС щодо застосування у різних умовах обстановки, місце (роль) у бойовому порядку (оперативній побудові) угруповання противника). 


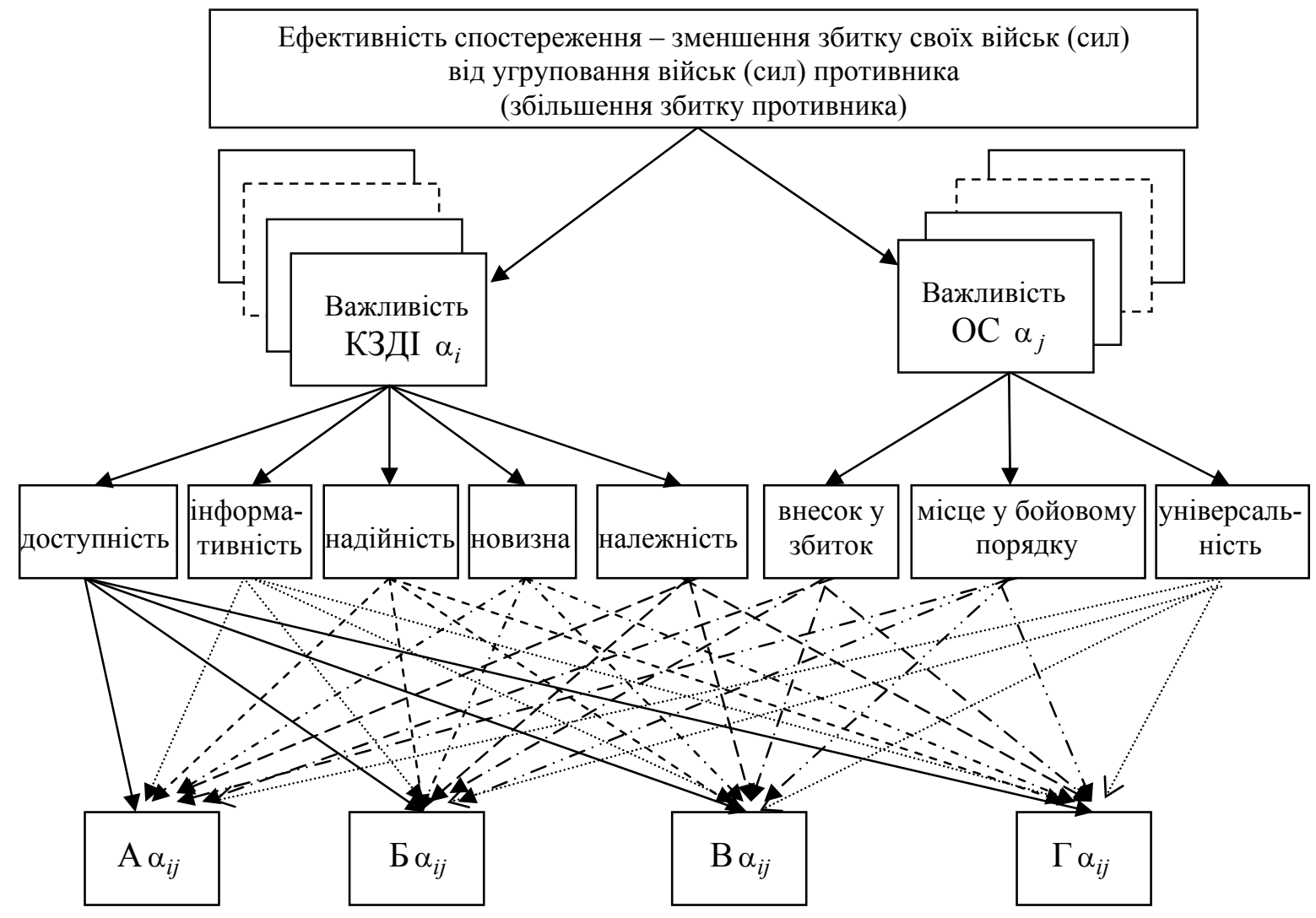

Рис. 1. Ієрархічна модель оцінювання важливості ОС та КЗДІ Джерело: розроблено авторами.

На основі експертного оцінювання кожному показнику надається певний ваговий коефіцієнт: $\alpha_{i}$ - для КЗДІ; $\alpha_{j}$ - для ОС. Передбачається, що експертне оцінювання ОС для визначення $\alpha_{j}$ здійснюється у підрозділах органу управління угруповання військ (сил), а експертне оцінювання ДІ для визначення $\alpha_{i}-$ у ГКП. У відповідності до $\alpha_{i}$ проводиться оцінювання за кожним показником кожного КЗДІ, за $\alpha_{j}$ - оцінювання ОС.

Спостереження здійснюється 3 використанням КЗДІ, що відрізняються за своїми можливостями (орбітальними параметрами, характеристиками апаратури спостереження, оперативністю, тощо) відносно кожного ОС та між собою. На етапі планування спостереження змістом суджень експертів щодо важливості джерел $є$ встановлення прогнозованого ступеня цінності інформації, отриманої від КЗДІ у належності до ОС певної важливості спостереження $-\alpha_{i j}$. Результатом роботи експертів $\epsilon$ перелік рангів джерел спостереження.

У системі планування варіант спостереження ОС характеризується показником $\alpha_{i j}$ - інтегральне визначення важливості кожного $j$-го ОС в угрупованні військ (сил) противника у аспекті (за умовою необхідності, можливості та раціональності) його спостереження з використанням космічних засобів, $i$-го КЗДІ.

При визначенні $\alpha_{i j}$ розуміємо, що ранги важливості ОС та КЗДІ не є сталими, а залежно від умов конкретної обстановки можуть змінюватися. Тому суть методичного апарату грунтується на комплексному врахуванні взаємозалежних і окремих чинників, які впливають на виконання завдань спостереження в операціях (бойових діях), а також у новому підході до визначення важливості ОС. За запропонованим підходом важливість ОС для планування його спостереження КЗДІ залежить не тільки від ступеню його небезпеки для військ (сил), але і від цінності (оперативності, точності, періодичності тощо) інформації про нього, яку можна добути за використанням МКЗ отриманих від космічних засобів, визначених (обмежених) ресурсом (час, фінанси, характеристики КЗДІ) виділеним на спостереження.

В разі виникнення ситуації, за якою об'єкт противника, якій є пріоритетним за можливістю нанесення збитку військам (силам), але не може бути визначений важливим для планування його космічного спостереження за ресурсом, ГКП повідомляє старший орган управління. Запропонований підхід дозволяє формалізувати процеси оцінювання важливості ОС та КЗДІ в інтересах подальшого розподілу наявного ресурсу, що є у розпорядженні ГКП 
для інформаційного забезпечення військ (сил) про об'єкти противника. Як показує аналіз відомих авторам результатів наукових досліджень, науковометодичних розробок, нормативних документів у предметній галузі, базовими елементами методичного апарату визначення важливості ОС та КЗДІ, можуть бути визначені так етапи:

- формування вимог (формування вихідної координатної (KI) та некоординатної (НКI) інформації);

- визначення умов;

- визначення ОС та КЗДІ;

- формування рангів ОС та КЗДІ (експертним методом);

- визначення важливості ОС (КЗДІ)[17].

Структура методики, зміст робіт та результати кожного $з$ п’яти етапів представлено на рис. 2.

Порядок виконання робіт першого, другого та третього етапів запропонованого підходу не суперечить відомим [11-13; 16] фахівцям підходам до підготовки вихідних даних, визначення умов, обмежень та припущень, що не викривлюють зміст процесів, та проведення оперативно-тактичних та інженернотехнічних розрахунків з моделювання (оцінювання, прогнозування, планування тощо) космічного спостереження наземних об'єктів.

На четвертому етапі основною вимогою (правилом) щодо визначення важливості, приймається те що вихідними даними для проведення експертного оцінювання та формування рангів ОС та КЗДІ, повинні бути: перелік ОС та КЗДІ, а також їх координатна (КI) та некоординатна (НКІ) інформація про них, що потрібна експертами при оцінювані їх важливості [14-15].

За прийнятими умовами експертне оцінювання ОС для визначення їх важливості за складовими $\alpha_{j}$, здійснюється у підрозділах органу управління угруповання військ (сил), а експертне оцінювання КЗДІ для визначення важливості - відповідно показників $\alpha_{i}-$ у ГКП.

Приклад оцінювання важливості КЗДІ (рис. 3).

У ході оцінювання обстановки умовно було встановлено можливість використання чотирьох КЗДІ $\left(D_{1}, D_{2}, D_{3}, D_{4}\right)$ для планування спостереження визначених ОС. Характеристики КЗДІ (космічні апарати, системи, оператори систем, матеріалів космічного знімання, тощо) вважаємо відомими фахівцям ГКП, які є експертами у предметній сфері космічної підтримки.

Для узгодженого визначення ГКП пріоритетності КЗДІ, кожен експерт визначає ранг важливості ДІ за власним розсудом, шляхом визначення місця кожного з них відносно інших, відповідно до уявлення експерту щодо значення КЗДІ для виконання завдань інформаційного забезпечення. Прийнято, що при проведенні оцінювання, КЗДІ за категоріями важливості визначаються рангами (місцями):

- найважливіше (першочергове) для I3 - ранг 1;

- важливе (першої категорії черговості) ранг 2;

- інше (другої категорії) - ранг 3;

- інше (третьої категорії) - ранг 4.

В разі надання експертом ГКП однакового пріоритету декількох КЗДІ щодо їх важливості для планування I3, він кожне 3 таких позначає однаковим для них середнім значенням рангу.

У ході оцінювання обстановки було визначено можливість використання чотирьох КЗДІ $\left(a_{i j}\left\{D_{1}, D_{2}, D_{3}, D_{4}\right\}\right)$ для планування спостереження. Характеристики КЗДІ відомі фахівцям ГКП, які є експертами у предметній сфері КП. Результати визначення рангів важливості КЗДІ, кожним експертом надано як приклад у табл. 1. Показано приклад однозначного оцінювання кожного КЗДІ експертами № 2, № 3, № 5 і № 6, а також особливості визначення однакового пріоритету декількох КЗДІ:

- експерт № 1 високо оцінює важливість джерела $D_{2}$ так саме як $D_{3}$, а $D_{1}$ і $D_{4}$ визначаються як інші другої та третьої категорії, відповідно, тому $D_{2}$ i $D_{3}$ позначаються середнім для них значенням рейтингу: $(1+2) / 2=1,5$;

- експерт № 4 оцінює $D_{2}$ як інше так саме як $D_{3}$, тому позначаються середнім для них значенням рейтингу: $(3+4) / 2=3.5$.

Таблиця 1

Результати визначення рангів важливості КЗДІ кожним з експертів ГКП

\begin{tabular}{|c|c|c|c|c|}
\hline $\begin{array}{c}\text { № } \\
\text { експерта }\end{array}$ & $D_{1}$ & $D_{2}$ & $D_{3}$ & $D_{4}$ \\
\hline 1 & 3 & 1.5 & 1.5 & 4 \\
\hline 2 & 3 & 1 & 4 & 2 \\
\hline 3 & 2 & 1 & 3 & 4 \\
\hline 4 & 2 & 3.5 & 3.5 & 1 \\
\hline 5 & 2 & 3 & 1 & 4 \\
\hline 6 & 1 & 3 & 2 & 4 \\
\hline
\end{tabular}

Джерело: розроблено авторами.

За наведеним прикладом, в ГКП має місце випадок неоднозначного уявлення щодо рангів важливості КЗДІ всіма експертами.

Для прийняття остаточного рішення щодо планування застосування КЗДІ на основі грунтовних пропозицій щодо їх рангів, потрібно провести опрацювання результати визначення рангів важливості КЗДІ кожним з експертів ГКП. У якості прикладу опрацювання результатів, що надано в табл. 1, рекомендовано сумісне використання методу середніх арифметичних та методу медіан рангів. 
Етап 1. Формування оперативно-тактичних вимог до спостереження (вихідна КІ та НКІ):

дані про противника та потенційні ОС;

дані про війська (сили), потенційні КЗДІ та ГКП, що здійснюють спостереження та інформаційне забезпечення за його результатами;

дані про обстановку та взаємне просторово-часове позиціонування потенційних ОС та КЗДІ

Етап 2. Формалізація тактико-технічних умов, припущень, обмежень (орбітальні параметри КА, цільові ТТХ КЗДІ):

забезпечення інформативності та своєчасної доступності КЗДІ до зони ведення спостереження ОС;

забезпечення оперативності, точності, достовірності, повноти інформаційного забезпечення за даними спостереження;

ресурсні обмеження

\section{Результат:}

визначення та формалізація вихідних даних щодо завдань інформаційного забезпечення за результатами спостереження потенційних ОС 3 використанням космічних засобів - КЗДІ, відповідно до завдань військ (сил)

\section{Етап 3. Визначення ОС та КЗДІ}

визначення у складі угруповання військ (сил) противника ОС, які відповідно до положень нормативних документів $є$ типовими (прийнятними) щодо їх спостереження; визначення КЗДІ, які відповідають вимогам та умовам спостереження ОС противника

\begin{tabular}{l} 
Результат: \\
$\begin{array}{l}\text { визначення такої, що є прийнятною, якості } \\
\text { iнформації від КЗДІ, у відповідності до кілько- } \\
\text { сті, КІ та НКІ про ОС, що визначені (за апріор- } \\
\text { ною інформацією) у складі противника, пара- } \\
\text { метрів зон спостереження (за варіантами) }\end{array}$ \\
\hline
\end{tabular}
метрів зон спостереження (за варіантами)

Етап 4. Експертним методом оцінювання та форму-
вання рангів ОС та КЗДI:
призначення експертів - фахівців 3 оцінювання ОС та
фахівців з оцінювання КЗДІ;
надання кожному експерту переліку ОС (КЗДІ), важли-
вість яких визначається;
опрацювання результатів визначення важливості ОС
(КЗДІ) методом середніх арифметичних рангів та методом
медіан їх рангів

\section{Етап 5. Методом Т. Сааті визначення важливості ОС} (КЗДІ)

підготовлення шкали порівнянь ОС (КЗДІ);

попарне порівняння відносної важливості ОС та за їх вкладом у збиток військ (сил), КЗДІ за їх вкладом і ефективність спостереження;

побудова матриці попарних порівнянь;

розрахунок вектору пріоритетів - важливості ОС (за отриманою матрицею передбачає розрахунок головного власного вектору, який після нормалізації стає вектором пріоритетів).

\section{Результат:}

перелік ОС та КЗДІ, визначення важливості яких потрібно для інформаційного забезпечення ГКП при плануванні спостереження

Рис. 2. Етапи визначення важливості ОС та КЗДІ Джерело: розроблено авторами.

Таблиця 2

Результати розрахунків та підсумкові ранги, що визначені методом середніх арифметичних

\begin{tabular}{|l|c|c|c|c|}
\hline \multicolumn{1}{|c|}{ Порядок розрахунку } & $D_{1}$ & $D_{2}$ & $D_{3}$ & $D_{4}$ \\
\hline 1. Сума рангів & 13 & 13 & 15 & 19 \\
\hline $\begin{array}{l}\text { 2. Середній арифметичний } \\
\text { ранг }\end{array}$ & 2.17 & 2.17 & 2.5 & 3.8 \\
\hline $\begin{array}{l}\text { 3. Підсумковий ранг за } \\
\text { середнім арифметичним }\end{array}$ & $1-2$ & $1-2$ & 3 & 4 \\
\hline
\end{tabular}

Джерело: розроблено авторами.

За результатами визначення рангів отримуємо

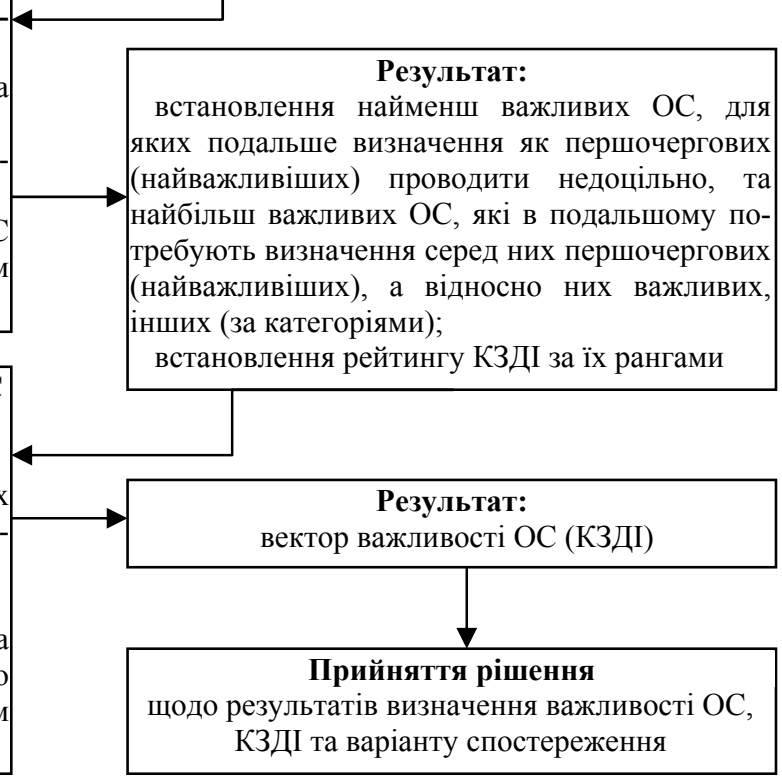




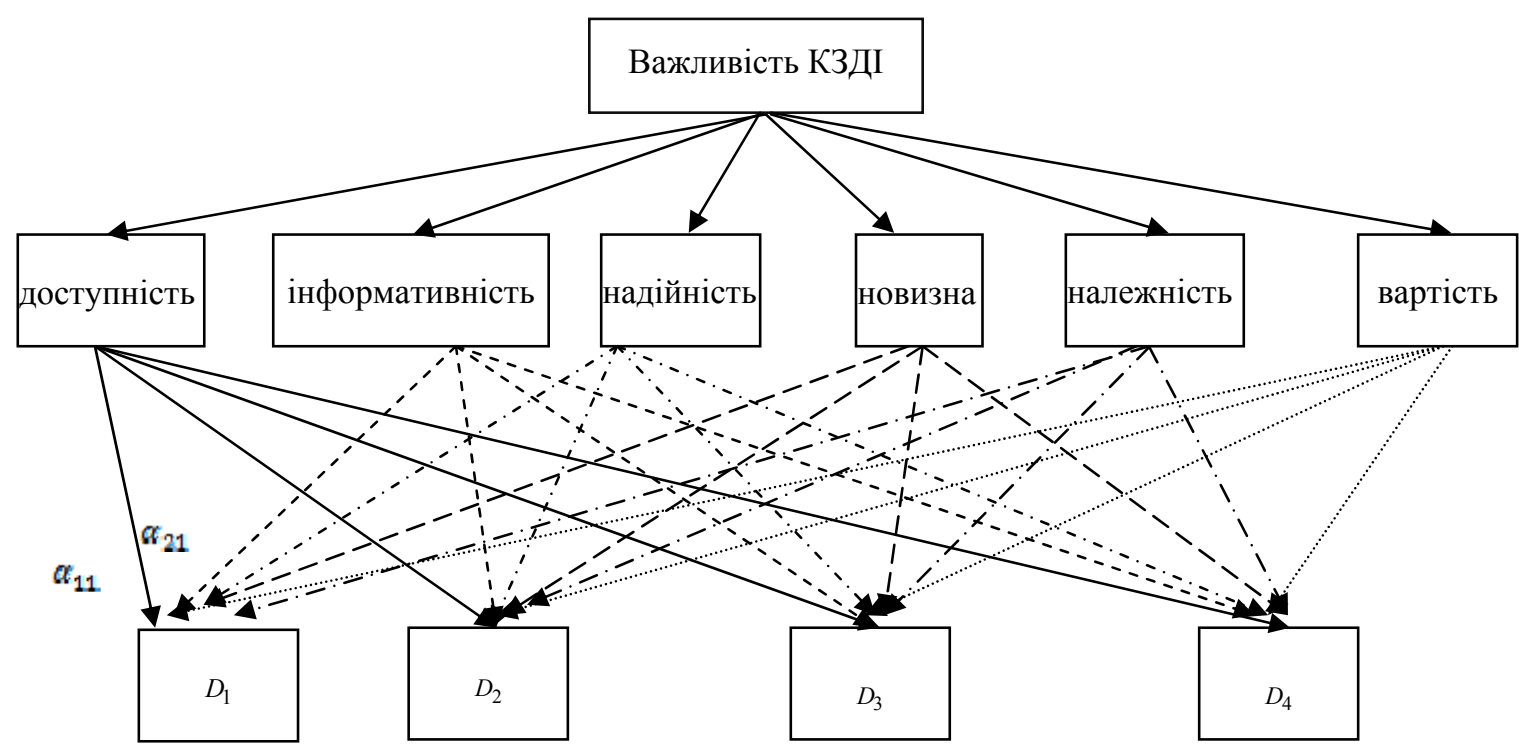

Рис. 3. Приклад моделі оцінювання важливості КЗДІ Джерело: розроблене авторами.

За результатами визначення рангів отримуємо варіант прийняття рішення на визначення важливості КЗДІ, шляхом ранжування за медіанами має вигляд:

$$
D_{1}<D_{2}<D_{3}<D_{4}
$$

Таблиця 3

Результати розрахунків та підсумкові ранги, що визначені методом медіан

\begin{tabular}{|c|c|c|c|c|}
\hline $\begin{array}{c}\text { Порядок } \\
\text { розрахунку }\end{array}$ & $D_{1}$ & $D_{2}$ & $D_{3}$ & $D_{4}$ \\
\hline $\begin{array}{c}1 . \text { Ранги в } \\
\text { порядку } \\
\text { не зменшення }\end{array}$ & $\begin{array}{c}1,2,2, \\
2,3,3\end{array}$ & $\begin{array}{c}1,1,1.5,3,3,5 \\
3,3.5\end{array}$ & $\begin{array}{c}1,1.5,2,3,3,4 \\
3.5,2,4,4, \\
4,4\end{array}$ \\
\hline $\begin{array}{l}2 . \text { Медіани } \\
\text { рангів }\end{array}$ & $(2+2): 2=2$ & $\begin{array}{c}(1.5+3): 2= \\
=2,25\end{array}$ & $\begin{array}{c}(2+3): 2=2,5 \\
=2,\end{array}$ & $\begin{array}{c}(4+4): 2= \\
=4\end{array}$ \\
\hline $\begin{array}{l}3 . \text { Підсумковий } \\
\text { ранг } \\
\text { за медіанами }\end{array}$ & 1 & 2 & 3 & 4 \\
\hline
\end{tabular}

Джерело: розроблено авторами.

Для підготовки рішення на визначення важливості необхідно порівняння ранжування (1) та (2). Результати ранжування свідчать як про схожість, так і про певні розбіжності в (1) та (2). Аналіз отриманих результатів дозволяють зробити висновки:

- найменш важливими є джерела $D_{3}$ та $D_{4}$; тому в подальшому їх оцінку як джерел КЗДІ про першочергові (найважливіші) ОС в інтересах I3 проводити недоцільно і в пропозиції на прийняття рішення не надавати;

- найбільш важливими є джерела $D_{1}$ та $D_{2}$, тому в подальшому їх оцінку як КЗДІ про першочергові (найважливіші) ОС в інтересах I3 проводити доцільно і в пропозиції на прийняття рішення нада- ти, 3 обов'язковою вказівкою пріоритету $D_{1}$ над $D_{2}$.

Необхідно відмітити, що при підготовці до виконання завдань спостереження при прийнятті рішення необхідно розроблювати два варіанта визначення важливості: основний та запасний на випадок змін обстановки, що обумовлюють неможливість реалізації дій за основним варіантом. В наведеному прикладі можливо розглядати джерело $D_{1}$ як основне - найважливіше, а джерело $D_{2}$ як запасне.

На n'ятому етапі здійснюється визначення варіантів спостереження (BC) за ознакою важливості OC [12] та підготовка пропозицій ОПР щодо організації спостереження та інформаційного забезпечення. Основним змістом дій п'ятого етапу є встановлення розподілу ресурсу на отримання МКЗ від космічних засобів, що визначені на попередньому етапі найбільш важливими КЗДІ, у залежності від категорії важливості ОС.

Важливість того чи іншого об'єкту [11-12; 16] визначається ступенем його впливу на величину втрат, які може нанести військам (силам) противник. Таким чином, в основу визначення пріоритетів ВС потрібно покласти збиток (втрати), який прогнозовано несуть наші війська (сили) від функціонування того чи іншого об'єкту противника.

При визначенні категорії важливості ОС противника потрібно враховувати, що втрат завдають не тільки об'єкти, що завдають безпосередні втрати засобами ураження. Втрати наших сил і засобів, що визначають збиток військ (сил), є наслідком функціонування ОС противника, що забезпечують бойову діяльність його засобів вогневого ураження та радіоелектронного подавлення. Діяльність таких ОС противника як сили та засоби розвідки, радіоелект- 
ронної боротьби, пункти управління, склади боєприпасів тощо, також впливають на втрати сил i засобів та величину збитку військ (сил).

Визначення категорії важливості об'єкта потребує кількісних оцінок, що передбачає вимірювання важливості, змістом якого є порівняння важливості ОС з певним еталоном (розрахунковою одиницею).

Для проведення попарного порівняння ОС та визначення пріоритетності варіантів спостереження, у якості “еталону” приймаємо об’єкти першої категорії - ОС першої категорії, які можуть безпосередньо впливати на війська (сили) у ході бойових дій з їх початку, тому у мирний час за ними ведеться періодичне спостереження.

Об'єкти, що можуть надати порівняно з ОС першої категорії більшого збитку військам (силам) iз початку бойових дій, визначаємо першочерговими OC, які потребують постійного спостереження та інформаційного забезпечення органів управління військ (сил) про їх стан та діяльність.

Об'єкти, що здатні надати порівняно з ОС першої категорії меншого збитку військам (силам), визначаємо ОС другої ( третьої) категорії, які потребують спостереження 3 отриманням відповідного завдання (з початком бойових дій).

Основними роботами п'ятого етапу є:

- підготовлення шкали порівнянь ОС;

- попарне порівняння відносної важливості ОС за ознакою важливості ОС щодо їх внеску у збиток військ (сил);

- побудова матриці попарних порівнянь ОС;

- розрахунок вектору пріоритетів ОС (за отриманою матрицею передбачає розрахунок головного власного вектору, який після нормалізації стає вектором пріоритетів).
Порядок переходу від вербального опису якісних характеристик ОС до їх формалізованого відображення, визначення категорії важливості ОС (джерел) розвідки $з$ використанням методу аналізу ієрархій [17] може бути наступним.

Вважаємо, що для раціонального розподілу КЗДІ та ефективного виконання завдання інформаційного забезпечення за результатами спостереження за системою ОС противника, потрібно порівняти попарно іiї елементи у оперативній побудові військ (сил) противника (при розгортанні у бойовий порядок).

Елементами структури системи ОС, порівняння яких проводимо є ОС типу: А, Б, В, Г (рис. 1). За припущеннями та обмеженнями, які не викривляють зміст та результати визначення категорії важливості ОС, вважаємо, що введення умови рівної категорії важливості декількох ОС одного типу не змінює змісту порівняння.

Порівняння елементів функціональної структури системи ОС противника здійснюється:

- за показником - ступенем їх впливу (внеску) на величину збитку військ (сил), який прогнозовано надасть система ОС, в разі не виконання завдань спостереження та інформаційного забезпечення ураження (подавлення) своєчасно розвіданих ії елементів;

- за критерієм - на скільки сильніше впливає на величину збитку один елемент у порівнянні 3 іншим.

Особа, що здійснює порівняння, з використанням значень, отриманих з застосуванням шкали відносин [17] (табл. 4) та значень ступенів категорії важливості (табл. 5), результат порівняння заносить у матрицю (табл. 6).

Таблиця 4

Шкала порівнянь ОС

\begin{tabular}{|c|c|c|}
\hline $\begin{array}{c}\text { Ступінь } \\
\text { переваги }\end{array}$ & Визначення переваги & Пояснення \\
\hline 1 & Однакова значність (значущість) & $\begin{array}{c}\text { Два ОС вносять однаковий вклад у величину збитку } \\
\text { військ (сил) }\end{array}$ \\
\hline 3 & $\begin{array}{c}\text { Певна перевага значності одного ОС } \\
\text { у порівнянні з іншим } \\
\text { (слабка значність) }\end{array}$ & $\begin{array}{c}\text { Можна стверджувати про різницю вкладів одного ОС у } \\
\text { порівнянні з іншим у величину збитку військ (сил) }\end{array}$ \\
\hline 5 & Суттєва або сильна значність & Надання сильної переваги одному ОС над іншим \\
\hline 7 & Дуже сильна (очевидна) значність & Перевага одного ОС перед іншим практично явна \\
\hline 9 & Абсолютна значність & $\begin{array}{c}\text { Свідчення на користь переваги ОС над іншим у вищому } \\
\text { ступені переконливі }\end{array}$ \\
\hline $2,4,6,8$ & $\begin{array}{c}\text { Проміжні значення між сусідніми } \\
\text { значеннями шкали } \\
\end{array}$ & Ситуація, що потребує компромісного рішення \\
\hline $\begin{array}{c}\text { Зворотні } \\
\text { величини } \\
\text { приведених } \\
\text { вище чисел }\end{array}$ & $\begin{array}{c}\text { Якщо } n \text {-му ОС при порівнянні з } k \\
\text { приписується одне } 3 \text { приведених ви- } \\
\text { ще чисел, то } k \text {-му об’єкту при порі- } \\
\text { внянні з } n \text {-м приписується зворотне } \\
\text { значення } \\
\end{array}$ & Обгрунтоване положення \\
\hline
\end{tabular}

Джерело: розроблено авторами з використанням [17]. 
Відносна важливість ОС (варіант)

\begin{tabular}{|c|c|c|c|c|}
\hline \begin{tabular}{|c} 
Ступінь \\
категорії \\
важливості
\end{tabular} & $\begin{array}{c}\text { Визначення } \\
\text { відносної категорії } \\
\text { важливості }\end{array}$ & $\begin{array}{c}\text { Нормативне } \\
\text { визначення категорії } \\
\text { важливості }\end{array}$ & $\begin{array}{c}\text { Пояснення щодо } \\
\text { впливу на наші війська } \\
\text { (сили) }\end{array}$ & $\begin{array}{c}\text { Кількісна } \\
\text { характеристика збитку } \\
\text { наших військ }\end{array}$ \\
\hline $\begin{array}{c}1 / 9 \\
\text { до } 0,11\end{array}$ & $\begin{array}{c}\text { Незначна } \\
\text { важливість }\end{array}$ & ОС третьої категорії & \multirow{2}{*}{$\begin{array}{c}\text { Утруднення реалізації } \\
\text { плану виконання } \\
\text { завдань за } \\
\text { призначенням } \\
\end{array}$} & $\begin{array}{c}\text { Бойовий потенціал } \\
\text { зменшується на 5-10\% }\end{array}$ \\
\hline $\begin{array}{c}1 / 7 \\
0,11-0,143 \\
\end{array}$ & $\begin{array}{c}\text { Значна } \\
\text { важливість }\end{array}$ & ОС другої категорії & & $\begin{array}{c}\text { Бойовий потенціал } \\
\text { зменшується на 10-15\% }\end{array}$ \\
\hline $\begin{array}{c}1 / 5 \\
0,143-0,2\end{array}$ & $\begin{array}{c}\text { Сильна (суттєва) } \\
\text { важливість }\end{array}$ & ОС перш & $\begin{array}{c}\text { Порушення реалізації } \\
\text { плану виконання } \\
\text { завдань за призначенням }\end{array}$ & $\begin{array}{c}\text { Бойовий потенціал } \\
\text { зменшується на 15-20\% }\end{array}$ \\
\hline $\begin{array}{c}1 / 3 \\
0,2-0,333\end{array}$ & $\begin{array}{c}\text { Дуже сильна } \\
\text { (очевидна) } \\
\text { важливість }\end{array}$ & Першочерговий ОС & \multirow{2}{*}{$\begin{array}{c}\text { Зрив реалізації плану } \\
\text { виконання завдань } \\
\text { за призначенням }\end{array}$} & $\begin{array}{c}\text { Бойовий потенціал } \\
\text { зменшується на 20-30\% }\end{array}$ \\
\hline $\begin{array}{c}1 \\
0,333-1\end{array}$ & $\begin{array}{l}\text { Абсолютна } \\
\text { важливість }\end{array}$ & Найважливіший & & $\begin{array}{c}\text { Бойовий потенціал } \\
\text { зменшується більш ніж } \\
30 \%\end{array}$ \\
\hline
\end{tabular}

Джерело: розроблено авторами з використанням [17].

Відповідно до [17] порівняння впливу завжди здійснюється для об'єкта (елемента, ОС), розмішеному у лівому стовпчику матриці, по відношенню до об'єкту, розмішеному у верхньому рядку. Після заповнення матриці потрібно знайти власний вектор 3 найбільшим значенням, що забезпечує впорядкування пріоритетів категорії важливості елементів, порівняння яких здійснюється. Пояснення роботи запропонованого методичного апарату на п'ятому етапі здійснено на прикладах.

Приклад 1. Загальний випадок: об'єкти А, Б, В, Г мають різні ступені переваги.

Отримуємо матрицю попарних порівнянь (табл. 6).

Таблиця 6 Матриця попарних порівнянь

\begin{tabular}{|c|c|c|c|c|}
\hline Важливість & А & Б & В & $\Gamma$ \\
\hline А & 1 & 5 & 6 & 7 \\
\hline Б & $1 / 5$ & 1 & 4 & 6 \\
\hline В & $1 / 6$ & $1 / 4$ & 1 & 4 \\
\hline$\Gamma$ & $1 / 7$ & $1 / 6$ & $1 / 4$ & 1 \\
\hline
\end{tabular}

Джерело: розроблено авторами.

Розрахунок вектору пріоритетів ОС за отриманої матрицею передбачає розрахунок головного власного вектору, який після нормалізації стає вектором пріоритетів.

Нормалізуємо табл. 6 по стовбцях (табл. 7)

Таблиця 7

Результати нормалізації

\begin{tabular}{|c|c|c|c|c|}
\hline Важливість & А & Б & В & $\Gamma$ \\
\hline А & 0,66 & 0,77 & 0,53 & 0,39 \\
\hline Б & 0,22 & 0,16 & 0,36 & 0,33 \\
\hline В & 0,11 & 0,04 & 0,09 & 0,22 \\
\hline$\Gamma$ & 0,09 & 0,03 & 0,02 & 0,06 \\
\hline
\end{tabular}

Джерело: розроблено авторами.
Нормалізуємо табл. 7 по рядках та отримаємо результат оцінювання відносної категорії важливостi OC:

- об'єкт А $(0,5875)$ - найважливіший ОС;

- об'єкт Б $(0,2675)$ - першочерговий ОС;

- об'єкт В $(0,115)$ - ОС другої категорії;

- об'єкт Г $(0,05)$ - ОС третьої категорії

Отримані результати надаються на затвердження ОПР.

Приклад 2. Випадок рівної категорії важливості А і Б між собою та у порівнянні з В та Г.

Отримуємо матрицю попарних порівнянь (табл. 8).

Таблиця 8

Матриця попарних порівнянь

\begin{tabular}{|c|c|c|c|c|}
\hline Важливість & А & Б & В & $\Gamma$ \\
\hline А & 1 & 1 & 6 & 7 \\
\hline Б & 1 & 1 & 6 & 7 \\
\hline В & $1 / 6$ & $1 / 6$ & 1 & 4 \\
\hline$\Gamma$ & $1 / 7$ & $1 / 7$ & $1 / 4$ & 1 \\
\hline
\end{tabular}

Джерело: розроблено авторами.

Аналогічно отримаємо табл. 9:

Таблиця 9

Результати нормалізації

\begin{tabular}{|c|c|c|c|c|}
\hline Важливість & А & Б & В & Г \\
\hline А & 0,433 & 0,433 & 0,453 & 0,368 \\
\hline Б & 0,433 & 0,433 & 0,453 & 0,368 \\
\hline В & 0,072 & 0,072 & 0,075 & 0,211 \\
\hline$\Gamma$ & 0,062 & 0,062 & 0,019 & 0,053 \\
\hline
\end{tabular}

Джерело: розроблено авторами.

Знайдемо результат оцінювання відносної категорії важливості ОС:

- об'єкт А $(0,421)$ - найважливіший $\mathrm{OC}$;

- об'єкт Б $(0,421)$ - найважливіший ОС; 
- об'єкт В $(0,109)$ - ОС другої категорії;

- об'єкт Г $(0,049)$ - ОС третьої категорії.

\section{Висновки}

Розроблений методичний апарат дозволяє визначати важливість ОС та КЗДІ 3 використанням методів експертного оцінювання та ранжування (на етапі визначення відносної категорії важливості КЗДІ), а також методів аналізу ієрархій та попарного порівняння (на етапі визначення категорії важливості ОС).

Розроблений методичний апарат визначення важливості об'єктів спостереження космічними засобами в інтересах інформаційного забезпечення груп космічної підтримки дозволяє:

- за рахунок формалізації процесу визначення важливості ОС КЗДІ, пропозиції щодо визначення їх категорії можуть надаватися ОПР у вигляді формалізованих варіантів для прийняття рішення з можли- вістю подальшої автоматизації цього процесу;

- використовувати послідовне використання результатів визначення категорії важливості, отриманих за нормативними характеристиками КЗДІ, для аналізу результатів розрахунків 3 визначення категорії важливості ОС, отриманих за їх відносним внеском у прогнозований збиток, що підвищує ефективність застосування;

- комплексне використання методів середніх арифметичних та медіан при обробленні результатів експертного оцінювання КЗДІ, що забезпечує більш коректне опрацювання наданих експертних оцінок.

Достовірність результатів, отриманих з застосуванням розробленого методичного апарату, забезпечується використанням добре відомих та апробованих методів (системного аналізу, експертних оцінок, суб'єктивних вимірювань, аналізу ієрархій) та несуперечність ним.

\section{Список літератури}

1. Алімпієв А.М. Особливості гібридної війни РФ проти України. Досвід, що отриманий Повітряними Силами Збройних Сил України / А.М. Алімпієв, Г.В. Пєвцов // Наука і техніка Повітряних Сил Збройних Сил України. - 2017. № 2(27). - С. 19-25. https://doi.org/10.30748/nitps.2017.27.03.

2. Оцінка можливостей виявлення об'єктів космічними засобами дистанційного зондування землі в інтересах інформаційного забезпечення груп космічної підтримки збройних сил / М.Ф. Пічугін, Д.А. Іщенко, О.О. Клімішен, Я.М. Кожушко // Системи озброєння та військова техніка. $\quad$ - 2018. - № 3(55). $\quad$ - С. 28-36. https://doi.org/10.30748/soivt.2018.55.04.

3. Попов М.О. Видова космічна розвідка в локальних військових конфліктах / М.О. Попов, М.В. Топольницький, В.О. Подліпаєв // Наука і оборона. - 2015. - № 1. - С. 25-35.

4. Воробйов О.В. Аналіз космічних апаратів дистанційного зондування Землі спеціального та подвійного призначення / О.В. Воробйов // Системи обробки інформації. - 2014. - № 6(122). - С. 28-30.

5. Худов Г.В. Використання супутникових даних в інтересах ведення контртерористичних операцій на прикладі операції “Geronimo" по знищенню “терориста №1” / Г.В. Худов // Системи озброєння і військова техніка. - 2011. № 1(25). - C. 185-189.

6. Теоретичні основи формування та деградації складних організаційно-технічних систем: монографія / Є.Б. Смірнов, В.І. Ткаченко, І.В. Рубан, В.Г. Малюга, А.В. Тристан. - Х.: ХНУРЕ, 2018. - 162 с.

7. Тристан А.В. Комплексна модель руйнування складних організаційно-технічних систем/ А.В. Тристан, Т.М. Курцева, В.Г. Паталаха // Збірник наукових праць Харківського національного університету Повітряних Сил. 2016. - № 4. - С. 100-104.

8. Теорія прийняття рішень органами військового управління: монографія / В.І. Ткаченко, Г.А. Дробаха, А.В. Тристан та ін.; за ред. В.І. Ткаченка, С.Б. Смірнова. - Х.: ХУПС. - 2008. - 545 с.

9. Підвищення ролі радіоелектронної боротьби за досвідом локальних війн / Я.М. Кожушко, Г.В. Мегельбей, А.І. Резниченко, Ю.А. Олійник // Збірник наукових праць Харківського національного університету Повітряних Сил. 2012. - № 3(32). - С. 79-81.

10. Тенденции развития авиационных средств радиоэлектронной борьбы военно-воздушных сил Соединенных Штатов Америки / Я.Н. Кожушко, А.И. Резниченко, Ю.А. Олейник, А.А. Михайлик // Наука і техніка Повітряних Сил Збройних Сил України. - 2011. - № 2(6). - С. 44-48.

11. Срмаков В.О. Розвідувальна підготовка. Противник II. Основи організації і ведення спостереження підрозділами / В.О. Єрмаков, С.І. Черняєв, В.І. Вінник. - Ж.: ЖВІ НАУ, 2010. - 116 с.

12. Військова розвідка / Д.В. Зайцев, А.П. Наконечний, С.О. Пахарєв, І.О. Луценко; за ред. В.Б. Добровольського. К.: Київський університет, 2016. -335 с.

13. Меньшаков Ю.К. Виды и средства иностранных технических разведок; под ред. М.П. Сычева. - М.: МГТУ им. Н.Э. Баумана, 2009. - 656 с.

14. Методологічні основи наукових досліджень. Математичне моделювання та оптимізація складних систем і процесів / І.Г. Грабар, М.О. Гуменюк, Ю.Г. Даник та ін. - Ж.: ЖВІ ДУТ, 2015. - 680 с.

15. Демидов Б.А. Методы военно-научных исследований / Б.А. Демидов. - Х.: ВИРТА ППО, 1987. - Ч. 2. - 486 с.

16. Бобриков А.А. Оценка эффективности огневого поражения ударами ракет и огнем артиллерии / А.А. Бобриков. - СПб.: Галея Принт, 2006. - 424 с.

17. Саати Т. Принятие решений. Метод анализа иерархии / Т. Саати. - М.: Радио и связь, 1993. -278 с. 


\section{Відомості про авторів:}

\section{Пічугін Михайло Федорович} кандидат військових наук професор провідний науковий співробітник Харківського Національного університету Повітряних Сил ім. І. Кожедуба, Харків, Україна https://orcid.org/0000-0002-8012-7487

Кожушко Ярослав Миколайович кандидат технічних наук старший науковий співробітник Харківського Національного університету

Повітряних Сил ім. І. Кожедуба

Харків, Україна

https://orcid.org/0000-0002-4229-6757

\section{Іщенко Дем'ян Андрійович}

кандидат технічних наук доцент

старший науковий співробітник наукового центру

Житомирського військового інституту ім. С. Корольова,

Житомир, Україна

https://orcid. org/ 0000-0001-9743-3889

\section{Кирилюк Володимир Анатолійович}

кандидат технічних наук старший науковий співробітник начальник науково-дослідної лабораторії

Житомирського військового інституту ім. С. Корольова, Житомир, Україна

https://orcid.org/0000-0003-3184-7944

Іщенко Сергій Дем'янович

старший офіцер військової частини А0515,

Київ, Україна

https://orcid.org/0000-0003-1358-1927

\section{Information about the authors:}

\section{Mikhail Pichugin}

Candidate of Military Sciences Professor

Lead Research

of Ivan Kozhedub Kharkiv National

Air Force University,

Kharkiv, Ukraine

https://orcid.org/0000-0002-8012-7487

Yaroslav Kozhushko

Candidate of Technical Sciences Senior Research Associate of Ivan Kozhedub Kharkiv National

Air Force University,

Kharkiv, Ukraine

https://orcid.org/0000-0002-4229-6757

\section{Demian Ishchenko}

Candidate of Technical Sciences

Associate Professor Senior Research Associate

of S.P. Korolyov Zhitomyr Military Institute,

Zhitomyr, Ukraine

https://orcid. org/ 0000-0001-9743-3889

\section{Volodymyr Kyryliuk}

Candidate of Technical Sciences Senior Research

Chief of Scientific Research Laboratory

of S.P. Korolyov Zhitomyr Military Institute,

Zhitomyr, Ukraine

https://orcid.org/0000-0003-3184-7944

Serhii Ishchenko

Senior Officer Military Unit A0515,

Kyiv, Ukraine

https://orcid.org/0000-0003-1358-1927

\title{
ОПРЕДЕЛЕНИЕ ВАЖНОСТИ ОБЪЕКТОВ НАБЛЮДЕНИЯ КОСМИЧЕСКИМИ СРЕДСТВАМИ В ИНТЕРЕСАХ ИНФОРМАЦИОННОГО ОБЕСПЕЧЕНИЯ ГРУПП КОСМИЧЕСКОЙ ПОДДЕРЖКИ
}

\section{М.Ф. Пичугин, Я.Н. Кожушко, Д.А. Ищенко, В.А. Кирилюк, С.Д. Ищенко}

В статье показана необходимость совершенствования методического аппарата информационного обеспечения космической поддержки всех видов деятельности вооруженных сил в группировках войск (сил), в том числе на тактическом уровне. Предложен методический аппарат оценивания важности объектов наблюдения и космических средств - источников информации о них, который может использоваться при организачии такого наблюдения в интересах эффективного применения войск (сил) по назначению с учетом необходимости рационального использования имеющихся возможностей космической поддержки.

Ключевые слова: важность, дистанционное зондирование земли, информация, космическая поддержка, съемка.

\section{DETERMINING THE IMPORTANCE OBSERVATION OBJECTS BY SPACE IN THE INFORMATION SUPPORT INTEREST OF SPACESUPPORT GROUPS}

\author{
M. Pichugin, Ya. Kozhushko, D. Ischenko, V. Kyryliuk, S. Ischenko
}

The article shows the need to improve methodological apparatus of information support for space support for all types of activities of the armed forces in groupings of troops (forces), including at the tactical level. A scientific and methodological apparatus for evaluating objects of observation and sources of information about them is proposed, which can be used when organizing such observation in the interests of the effective use of troops (forces) for their intended purpose, taking into account the need for rational use of available forces and means of space support. It is proposed to solve the problem of formalization and adaptation by developing a methodology for determining the importance of objects of observation and spacecraft - sources of information about them. A method of quantitative assessment of the relative importance objects of observation and sources of information, based on the construction and analysis of their quality indicators. The structure of indicators of quality of objects and possibilities of their supervision are substantiated, the specialized scales of pair comparison of objects on indicators of different kind are offered. At the same time, the proposed methodology takes into account, in terms of importance, the quality indicators of space-based means of observation and objects of observation, the information about which they should provide, allows to choose rational options for information support tasks using space support groups. The scientific novelty of the results of the work is to improve the mathematical apparatus for determining the importance of objects of observation and sources of information about them, which makes it possible to automate this process when planning information support in groups of troops (forces). The practical significance of the research results is the possibility of increasing the efficiency of determining the importance of objects and sources of space survey materials and preparing proposals for improving information support in groups of troops.

Keywords: earth remote sensing, importance, information, observation, space support, survey. 